Jap. J. Limnol. 44, 3, 184-189, 1983.

\title{
Food Selection of the Ciliated Protozoa, Condylostoma vorticella (Ehrenberg) in Lake Kasumigaura
}

\author{
Noriko TAKAMURA and Masayuki YASUnO
}

\begin{abstract}
The food selection of a herbivorous ciliated protozoa, Condylostoma vorticella (Ehrenberg) was examined in November 1980 in Takahamairi Bay of Lake Kasumigaura, using IvLev's (1955) electivity index. This ciliated protozoa selectively fed on Synechococcus, Kirchneriella, Dictyosphaerium, Coscinodiscus, Cryptomonas, Chlamydomonas, and Gomphosphaeria, but rejected Closterium, Phormidium, Synedra, Tetrastrum, Dactylococcopsis, Scenedesmus, Aphanizomenon, Melosira, and Micractinium. The size and shape of algae were significant in the food selection, but the taxonomical groups were insignificant. The ciliate fed efficiently on food particles between $15 \mu \mathrm{m}$ and $40 \mu \mathrm{m}$ in size, but not filamentous and spindlelike algae or algae with long spines.

Colonies of Microcystis found most abundantly in this lake were preferably ingested by the ciliate. This ciliated protozoa is likely a significant link in the food chain between Microcystis and crustacean zooplankton.
\end{abstract}

\section{Introduction}

Ciliated protozoa are important in freshwater ecosystems not only as food links between bacteria and crustacean zooplankton (Porter et al., 1979) but also as an abundant component of zooplankton communities (PACE and ORCUTT, 1981). However, their role has often been ignored because of the difficulty in fixing and preserving samples for proper species identification. Also, there is no appropriate sampling method for determining the abundance and distribution of the protozoa. The density of ciliates in Lake Kasumigaura in November 1980 was $10^{3}$ to $10^{5} \cdot l^{-1}$, which was of the same order as reported in other eutrophic waters (BAMFORTH, 1958; Sorokin and Paveljeva, 1972; Pace and OrcutT, 1981). Therefore, ciliated protozoa should be considered an important component in this lake.

Selective feeding by ciliates was reported by Curds (1977). Recently, HeinboKeL (1978) and Fenchel (1980 a, b) discussed the size of food particles consumed by ciliates. The present reporters investigated the food of the herbivorous ciliated protozoa Condylostoma vorticella (Ehrenberg), abundantly present in Takahamairi Bay, and found that both the size of food particles and their shape have an influence on its feeding.

The authors express their appreciation to Dr. R. Sudo and Dr. Y. InAmori of the National Institute for Enviromental Studies for their identification of the protozoa.

\section{Study Sites and Methods}

This study was carried out at Takahamairi Bay in Lake Kasumigaura, a highly eutrophic body of water. Heavy blooms of Microcystis occur every summer and autumn in this lake. Water samples were taken from a $0.5 \mathrm{~m}$ depth by a VanDorn sampler on 7th, 10th, and 13th November 1980 , when the water temperature was $13.0^{\circ} \mathrm{C}, 12.0^{\circ} \mathrm{C}$, and $15.5^{\circ} \mathrm{C}$, respectively. During the course of this study, dissolved oxygen varied from 10.3 to $16.9 \mathrm{ppm}, \mathrm{pH}$ from 7.3 to 9.2 , and chlorophyll $a$ from 108.4 to $136.8 \mathrm{mg} \cdot \mathrm{m}^{-3}$. The concentration of ammonium nitrogen, nitrite plus nitrate nitrogen, and reactive phosphate, did not change much, ranging from 0.117 to $0.156 \mathrm{mg} \cdot l^{-1}$, from 1.178 to $1.289 \mathrm{mg} \cdot l^{-1}$, and from 0.004 to $0.007 \mathrm{mg}$. $l^{-1}$, respectively (IwaKuma et al., 1982). Aliquot water samples of $100 \mathrm{~m} l$ were fixed immediately after sampling with Lugol's 
iodine solution for identification and counting of phytoplankton by the UTERMÖHL method (UTERMÖHL, 1958) on the respective day. Condylostoma vorticella (Fig. 1) was sorted out from the other aliquot water samples by capillary pipettes under a binocular microscope within two to six hours after sampling, and the species and number of algae in ciliates were identified and counted under a microscope. A total of 101 individual ciliates were observed.

\section{Results}

Figure 2 shows the percentage composition of the algal species in Condylostoma

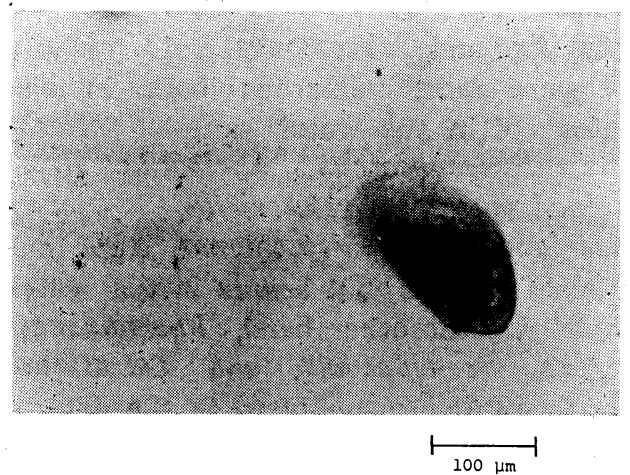

Fig. 1. The photograph of the ciliate Condylostoma vorticella (Ehrenberg). vorticella and that in the natural water

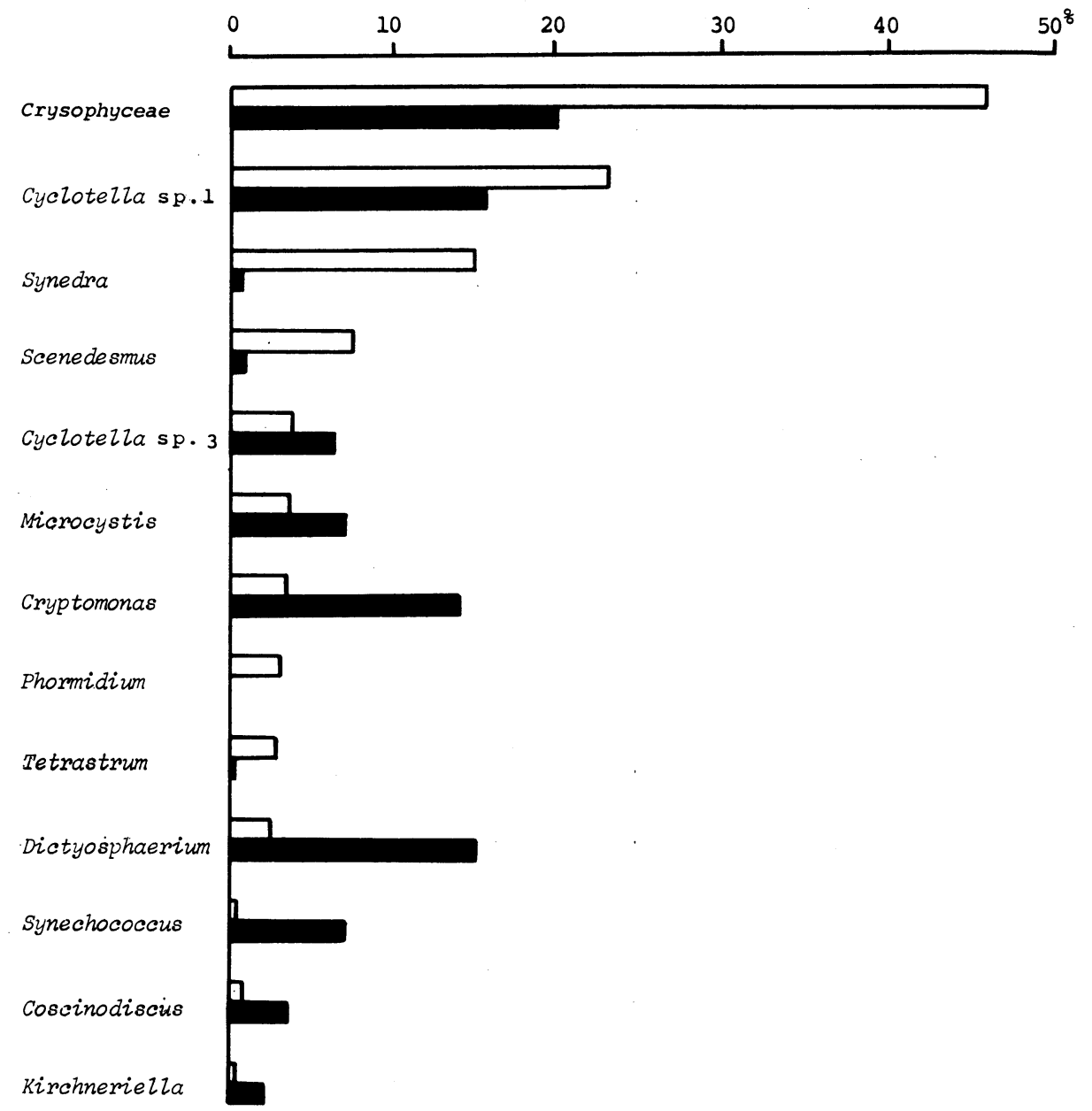

Fig. 2. The percentage composition of the algal species in Condylostoma vorticella (solid) and that in the natural water (open). 
sample. Chrysophyceae (mostly Chrysochromulina and Ochromonas) and Cyclotella sp. 1 were most numerous both in the ciliates and in the water sample. Microcystis, Synechococcus, Cyclotella sp. 3, Coscinodiscus, Kirchneriella, Dictyosphaerium, and Cryptomonas were numerousin ciliates but scarce in the water sample. On the other hand, Phormidium, Synedra, Scenedesmus, and Tetrastrum were frequently encountered in the natural water, but only rarely in ciliates. These phenomena indicate that $C$. vorticella selectively feed on particular species of algae.

To evaluate the selection of algal species by $C$. vorticella IVLEv's (1955) electivity index $(\mathrm{E}=(\mathrm{R}-\mathrm{P}) /(\mathrm{R}+\mathrm{P})$ was used, where $R$ was the proportion of the algal species taken in the ciliate and $\mathrm{P}$ the proportion of that species in the natural water. Table 1 shows the indices calculated for 36 taxa. Condylostoma vorticella rejected Phormidium, Dactylococcopsis, Aphanizomenon, Synedra, Melosira, Closterium, Tetrastrum, Scenedesmus, and Micractinium, and preferred Synechococcus, Gomphospihaeria, Coscinodiscus, Kirchneriella, Dictyosphaerium, Chlamydomonas, and Cryptomonas. No judgement could be made for the species that appeared less frequently in the water sample. Thus, the ciliate did not necessarily select specific taxonomical groups such as blue-green algae or diatoms.

The morphological characteristics and size of the algae seemed to be very significant factors in food selectivity. Filamentous algae such as Melosira, Aphanizomenon, and Phormidium, algae whose shape is spindlelike as in the case of Closterium, Synedra, and Dactylococcopsis, and those having long spines such as Micractinium, Scenedesmus, and Tetrastrum were apparently rejected. In the case of unicellular species, the larger species (15-30 micrometers long) such as Coscinodiscus, Cryptomonas, Chlamydomonas, and Euglena seemed to be consumed more frequently than the smaller species (5-7 micrometers long) such as Cyclotella sp. 1, Chrysochromulina, and
Ochromonas. The ciliate could feed on colonies approximately 20-40 micrometers long which consisted of about 20 cells in the case of Microcystis and about 16 in the case of Dictyosphaerium.

\section{Discussion}

LEE et al. (1966) reported that foraminifera selected particular taxonomical groups such as diatoms and chlorophytes. In the case of the ciliate Condylostoma vorticella, the size and shape of algae were more significant in food selectivity than the taxonomical groups of the algae. In the present study, Condylostoma vorti. cella efficiently took algae of $15 \mu \mathrm{m}$ to $40 \mu \mathrm{m}$. This seems to be consistent with FENCHEL's general conclusions (1980 a) that 14 species of ciliates each showed a distinct spectrum in the size of particles retained. As FENCHEL (1980 b, c, d) described, the range of particle size ingested by $C$. vorticella might be explained by the shape and size of the mouth of this species; food particles larger than $40 \mu \mathrm{m}$ cannot enter the relatively smaller buccal cavity, and particles smaller than $15 \mu \mathrm{m}$ passing between the adjoining membranelles cannot be collected.

The ciliates did not feed on filamentous or spindlelike algae nor algae with long spines. McNaught et al. (1980) showed that sheathed algae were not eaten by the copepod, Diaptomus sicilis and certain cyclopoids. However, the sheath of algae was insignificant for uptake by the ciliate, since Synechococcus and Microcystis were consumed to a considerable degree.

It has been reported that colonies or filaments of blue-green algae are not utilized by filter feeders (MCMAHON and RIGLER, 1963; BUrns, 1968; Porter, 1977). The bloom of Microcystis in Lake Kasumigaura has been explained by the lack of zooplankton which ingest colonies of this alga. Yамамото (1978) found amoebatic protozoa which feed on Microcystis. The present investigators also found that $C$. vorticella also feed on Microcystis. Since BERK et al. (1977) and PORTER et al. (1979) 
Table 1. Number of cells and percentage composition of algal species in Condylostoma vorticella, percentage composition of them in the water sample and IvLev's electivity index.

\begin{tabular}{|c|c|c|c|c|}
\hline & $\begin{array}{l}\text { Number of } \\
\text { cells counted } \\
\text { in } \\
\text { Condylostoma } \\
\text { vorticella }\end{array}$ & $\begin{array}{l}\text { Percentage } \\
\text { composition } \\
\text { in } \\
\text { Condylostoma } \\
\text { vorticella }\end{array}$ & $\begin{array}{l}\text { Percentage } \\
\text { composition } \\
\text { in the } \\
\text { water } \\
\text { sample }\end{array}$ & $\begin{array}{l}\text { IvLEv's } \\
\text { electivity } \\
\text { index }\end{array}$ \\
\hline \multicolumn{5}{|l|}{ Blue-green algae } \\
\hline Anabaena spp. & 20 & 0.75 & 1.01 & -0.15 \\
\hline${ }^{\circ}$ Aphanizomenon flos-aquae & 3 & 0.11 & 0.56 & -0.67 \\
\hline Microcystis aeruginosa & 187 & 7.01 & 3. 60 & 0.32 \\
\hline${ }^{\circ}$ Gomphosphaeria sp. & 13 & 0.49 & 0.19 & 0.44 \\
\hline${ }^{\circ}$ Phormidium tenue & 0 & 0 & 3.12 & -1.00 \\
\hline Synechococcus sp. & 181 & 6.79 & 0.21 & 0.94 \\
\hline Dactylococcopsis sp. & 4 & 0.15 & 1.93 & -0.86 \\
\hline \multicolumn{5}{|l|}{ Diatoms } \\
\hline Coscinodiscus sp. & 97 & 3.64 & 0.72 & 0.67 \\
\hline Cyclotella sp. 1 & 415 & 15.57 & 23.17 & -0.20 \\
\hline Cyclotella sp. 2 & 4 & 0.15 & 0.30 & 0.33 \\
\hline Cyclotella sp. 3 & 168 & 6.30 & 3.86 & 0.24 \\
\hline Melosira spp. & 16 & 0.60 & 1.74 & -0.49 \\
\hline Synedra spp. & 18 & 0.68 & 14.76 & -0.91 \\
\hline Attheya sp. & 1 & 0.04 & 0.00 & 0.82 \\
\hline Achnanthes sp. & 9 & 0.34 & 0.03 & 0.84 \\
\hline Attached algae & 12 & 0.45 & 0.02 & 0.91 \\
\hline \multicolumn{5}{|l|}{ Green algae } \\
\hline Actinastrum sp. & 8 & 0.30 & 0.05 & 0.71 \\
\hline Ankistrodesmus sp. & 1 & 0.04 & 0.03 & 0.14 \\
\hline Kirchneriella sp. & 57 & 2.14 & 0.12 & 0.89 \\
\hline Closterium aciculare & 0 & 0 & 0.56 & -1.00 \\
\hline Dictyosphaerium sp. & 397 & 14.89 & 2.43 & 0.72 \\
\hline Mougeotia sp. & 0 & 0 & 0.07 & -1.00 \\
\hline Micractinium sp. & 8 & 0.30 & 1.15 & -0.59 \\
\hline Scenedesmus spp. & 24 & 0.90 & 7.54 & -0.79 \\
\hline Staurastrum sp. & 2 & 0.08 & 0.01 & 0.87 \\
\hline Tetraedron sp. & 1 & 0.04 & 0.04 & 0.04 \\
\hline Tetrastrums sp. & 4 & 0.15 & 2.88 & -0.90 \\
\hline Chlamydomonas spp. & 28 & 1.05 & 0.40 & 0.45 \\
\hline Euglena sp. & 6 & 0.23 & 0.10 & 0.39 \\
\hline Trachelomonas sp. & 1 & 0.04 & 0.02 & 0.45 \\
\hline${ }^{*}$ Green coccoidal & 37 & 1.39 & - & - \\
\hline \multicolumn{5}{|l|}{ Chrysophyceae } \\
\hline Dinobryon sp. & 1 & 0.04 & 0.02 & 0.45 \\
\hline Mallomonas sp. & 1 & 0.04 & 0.00 & 0.82 \\
\hline Others & 536 & 20.11 & 46.12 & -0.39 \\
\hline Cryptophyceae & 372 & 13.95 & 3. 46 & 0.60 \\
\hline Dinophyceae & 2 & 0.08 & 0.02 & 0.57 \\
\hline
\end{tabular}

': Number of colonies or filaments instead of cells was counted for these algae.

*: Species could not be identified. 
reported that ciliates were consumed by copepod, Eurytemora and cladoceran, Daphnia, it may be concluded that $C$. vorticella may be a significant link in the food chain between Microcystis and crustacean zooplankton in Lake Kasumigaura.

\section{摘 要}

霞ケ浦高浜入で 1980 年 11 月に藻食性織毛虫 Condylostoma vorticella (Ehrenberg) の食物選択性を 調べた。食物造択性は，IVLEV (1955) の選択指数を 用いて表わした.

選択性の高かった澡類は, 藍澡のSynechococcus, Gomphosphaeria, 珪藻の Coscinodiscus, 緑藻の Kirchneriella, Dictyoshaerium, Chlamydomonas, クリプト藻のCryptomonas であった。一方選択性の 低かった藻類は, 藍藻の Phormidium, Dactylococcopsis, Aphanizomenon, 珪藻の Synedra, Melosira, 緑藻の Closterium, Tetrastrum, Scenedesmus, Micractinium であり, この織毛虫が, 特定の分類群 の藻類を好むという傾向は，認められなかった。

取り込まれやすい澡類のサイズは $15 \mu \mathrm{m}$ から 40 $\mu \mathrm{m}$ であったが，ての䇚用内であっても糸状性の澡頪 および針状の棘を持つ藻類は, 取り込まれにくいとと がわかった。

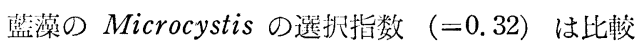
的高く, 乙の繊毛虫が霞ヶ浦の生態系において Microcystis と浮遊性甲殼類の食物連鎖に重望な役制 を果たしている可能性を短知するてとができた。

\section{References}

Bamforth, S.S. (1958): Ecological studies on the planktonic protozoa of a small artificial pond. Limnol. Oceanogr., 3: 398-412.

Berk, S. G., D. C. Brownlee, D. R. Heinle, H. J. Kling and R. R. Colwell (1977) : Ciliates as a food source for marine planktonic copepods. Microb. Ecol., 4: 27-40.

Burns, C.W. (1968) : Direct observations of mechanisms regulating feeding behavior of Daphnia, in lakewater. Int. Revue ges. Hydrobiol., 53: 83-100.

Curds, C.R. (1977) : Microbial interactions involving protozoa, p.69-105. In: F.A. Skinner and J. N. Shewan (ed.), Aquatic Microbiology. Academic press.

Fenchel, T. (1980a): Suspension feeding in ciliated protozoa: functional response and particle size selection. Microb. Ecol., 6: 111.

Fenchel, T. $(1980 \mathrm{~b})$ : Suspension feeding in ciliated protozoa: feeding rates and their ecological significance. Microb. Ecol., 6 : 13-25.

Fenchel, T. (1980 c): Suspension feeding in ciliated protozoa: structure and function of feeding organelles. Arch. Protistenk., 123: $230-260$.

Fenchel, T. $(1980 \mathrm{~d})$ : Relation between particle size selection and clearance in suspensionfeeding ciliates. Limnol. Oceanogr., 25: 733-738.

Heinbokel, J.F. (1978): Studies on the functional role of tintinnids in the southern California Bight. II. Grazing rates of field populations. Mar. Biol., 47: 191-197.

Ivlev, B. C. (1955) : (trans. Kodama, Y. and T. Yoshinara, 1965). Experimental Ecology of the Feeding of Fishes. $10+261$ pp. Tatara, Yonago.

Lee, J. J., M. McEnery, S. Pierce, H. D. Freudenthal and W.A. Muller (1966): Tracer experiments in feeding littoral foraminifera. J. Protozool., 13: 659-670.

Imakuma, T., A. Otsuki, M. Aizaki, N. Imamura, T. Hanasato and M. Yasuno (1982): Enclosure experiments for restoration of Lake Kasumigaura. Survey Rep. Nat. Inst. Environ. Stu., 21: 15-35.

McMahon, J.W. and F. H. Rigler (1963) : Mechanisms regulating the feeding rate of Daphnia magna Straus. Can. J. Zool., 41: 321-332.

McNaught, D. C., D. Griesmer and M. Kennedy (1980) : Resource characteristics modifying selective grazing by copepods, p. 292-298. In: W.C. Kerfoot (ed.), Evolution and Ecology of Zooplankton Communities. The University Press of New England.

Pace, M.L. and J.D.Jr. Orcutt (1981): The relative importance of protozoans, rotifers, and crustaceans in a freshwater zooplankton community. Limnol. Oceanogr., 26: 822830.

Porter, K. G. (1977) : The plant-animal interface in fresh-water ecosystems. Am. Sci., 65: 159-170.

Porter, K. G., M. L. Pace and J.F. Battey (1979) : Ciliate protozoans as links in freshwater planktonic food chain. Nature, Lond. 277: 563-565.

Sorokin, Yu. I. and E. B. Paveljeva (1972) : On the quantitative characteristics of the pelagic ecosystem of Dalnee lake (Kamchatka). Hydrobiologia, 40: 519-552.

UtermöHL, H. (1958) : Zur Vervollkommung der quantitativen Phytoplankton-Methodik. Mitt. Internat. Verein. Limnol., 9: 1-38. 
Yамамото, Y. (1978) : Detection of algal lysing biological agents in lakes by the soft-agar overlayer technique. Jap. J. Limnol., 39: 9-14.

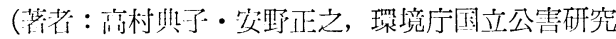
所生物環境部，茨城具筑波郡信四部町小野川 16-2,
305 ; Noriko Takamura aud Masayuki Yasuno, Enviromental Biology Division, National Institute for Environmental Studies, Yatabe, Tsukuba, Ibaraki 305)

Accepted: 29 January 1983 